\title{
PENERAPAN MODEL PROBLEM BASED LEARNING UNTUK MENINGKATKAN MOTIVASI DAN HASIL BELAJAR SISWA DENGAN PEMBELAJARAN ILMU PENGETAHUAN SOSIAL PADA MATERI PENINGGALAN SEJARAH KERAJAAN BUDDHA DI INDONESIA
}

\author{
Dr. H. Mamur Sutisna WD.M.MPd. ${ }^{1}$ \\ Ai Robiatul Ulumiah² \\ 1Dosen Universitas Subang \\ ${ }^{2}$ Mahasiswa Universitas Pasundan
}

\begin{abstract}
This study aims to improve students' motivation and learning outcomes through learning Social Scienceby applying the model of Problem Based Learning. This research is motivated by the problems that occur in the classroom, namely the lack of motivation and student learning outcomes. The design of this study used a classroom action research model consisting of three cycles, each cycle conducted in two meetings, including the planning stage, action implementation, interview observation, documentation, analysis and reflection. The results showed that through the application of Probem Based Learning model can improve the motivation and learning outcomes of students with Social Sciencelearning on the material of the historical relics of the Buddhist kingdom in Indonesia. This can be seen from the results of observation and analysis which shows that the assessment of RPP cycle I reached the percentage of $67.5 \%$ enough category, cycle II reached the percentage of $77.5 \%$ good category, cycle III reached the percentage of $90 \%$ very good category. Implementation of learning in the first cycle reached the percentage of $62.9 \%$ enough category, cycle II reached the percentage of $77.5 \%$ good category, cycle III reached the percentage of $90 \%$ very good category. While the results of students' learning motivation cycle I reached the percentage of $65 \%$ enough category, cycle II reached the percentage of $75.7 \%$ good category, cycle III reached the percentage of $88 \%$ very good category. Similarly, the results of student learning that meets the value of $K K M$ in cycle I reached the percentage of $59 \%$ enough category, cycle II reached the percentage of $73 \%$ good category, cycle III reached the percentage of $90 \%$ very good category. Classroom action research ends in cycle III because the aspects studied are considered to have succeeded in achieving the indicator of achievement determined. This is because the model of Problem Based Learning is the appropriate learning resources for student development in Social Sciencelearning related to daily life. Based on the above description, it can be concluded that the model of Problem Based Learning can improve the motivation and student learning outcomes with Social Sciencelearning on the material of the historical relics of the Buddhist kingdom in Indonesia.
\end{abstract}

Keywords: Problem Based Learning, Motivation, Student Learning Outcomes, Social ScienceLearning 


\begin{abstract}
ABSTRAK
Penelitian ini bertujuan untuk meningkatkan motivasi dan hasil belajar siswa melalui pembelajaran IPS dengan menerapkan model Problem Based Learning. Penelitian ini dilatarbelakangi oleh masalah yang terjadi di dalam kelas, yaitu kurangnya motivasi dan hasil belajar siswa. Desain penelitian ini menggunakan model penelitian tindakan kelas yang terdiri dari tiga siklus, setiap siklus dilakukan dalam dua kali pertemuan, meliputi tahap perencanaan, pelaksanaan tindakan, observasi wawancara, dokumentasi, analisis dan refleksi. Hasil penelitian menunjukan bahwa melalui penerapan model Probem Based Learning dapat meningkatkan motivasi dan hasil belajar siswa dengan pembelajaran IPS pada materi peninggalan sejarah kerajaan Buddha di Indonesia. Hal ini dapat dilihat dari hasil observasi dan analisis yang menunjukan bahwa penilaian RPP siklus I mencapai persentase $67.5 \%$ kategori cukup, siklus II mencapai persentase $77,5 \%$ kategori baik, siklus III mencapai persentase 90\% kategori sangat baik. Pelaksanaan pembelajaran pada siklus I mencapai persentase 62,9\% kategori cukup, siklus II mencapai persentase $77,5 \%$ kategori baik, siklus III mencapai persentase $90 \%$ kategori sangat baik. Sementara hasil motivasi belajar siswa siklus I mencapai persentase 65\% kategori cukup, siklus II mencapai persentase $75,7 \%$ kategori baik, siklus III mencapai persentase $88 \%$ kategori sangat baik. Begitu pula dengan hasil belajar siswa yang memenuhi nilai KKM di siklus I mencapai persentase 59\% kategori cukup, siklus II mencapai persentase 73\% kategori baik, siklus III mencapai persentase $90 \%$ kategori sangat baik. Penelitian tindakan kelas berakhir di siklus III karena aspek yang diteliti dianggap telah berhasil menempuh indikator ketercapaian yang ditentukan. Hal itu dikarenakan model Problem Based Learning merupakan sumber belajar yang tepat untuk perkembangan siswa dalam pembelajaran IPS yang berkaitan dengan kehidupan seharihari. Berdasarkan uraian di atas, dapat disimpulkan bahwa model Problem Based Learning mampu meningkatkan motivasi dan hasil belajar siswa dengan pembelajaran IPS pada materi peninggalan sejarah kerajaan Buddha di Indonesia.
\end{abstract}

Kata Kunci: Problem Based Learning, Motivasi, Hasil Belajar Siswa, Pembelajaran IPS

\section{A. PENDAHULUAN}

Pendidikan merupakan usaha manusia untuk menyiapkan diri dalam mengahadapi tantangan global yang akan datang .

Pendidikan dilakukan tanpa ada batasan usia, ruang dan waktu yang tidak hanya dilakukan di sekolah dan diperkarya oleh lingkungan masyarakat yang memungkinkan hasilnya digunakan untuk membangun kehidupan pribadi secara agama, keluarga , masyarakat, dan Negara 
merupakan suatu kenyataan bahwa pemerintah dalam hal ini diwakili lembaga yang bertanggung jawab didalam pengelolaan pendidikan di Indonesia. Namun pada kenyataannya harus disadari bahwa pendidikan tidak hanya menjadi tanggung jawab keluarga, sekolah dan masyarakat yang sering disebut dengan Tri Pusat Pendidikan.

\section{Pendidikan}

menurut

Kurniasih (2010, hlm. 21) disampaikan oleh pendidik dan diterima oleh peserta didik. Telah kita pahami, hakikatnya manusia adalah mahluk sosial, ia hidup bersama dengan sesamanya, dalam kehidupan bersama dengan sesamanya ini akan terjadi hubungan pengaruh timbal balik dimana setiap individu akan menerima pengaruh dari individu yang lainnya.

Sementara menurut Berg (2010, hlm. 5) dalam buku pengantar kependidikan karangan Prof. Dr. Sudarwan Danim : "pendidikan adalah proses menjadi orang yang berpendidikan. Menjadi orang yang berpendidikan berarti manusia menjalani proses pencerdasan dan pengembangan potensi secara kontinyu dan optimum".

Berdasarkan pendapat di atas, peneliti menyimpulkan bahwa pendidikan merupakan proses membantu orang untuk mengubah sikap prilaku pembelajaran yang disampaikan oleh pendidik dan diterima oleh peserta didik. Pendidikan dalam perkembangan kehidupan sosial masyarakat sangat memegang peranan penting sebagai suatu bekal dan pandangan bagi setiap individu yang berada di dalam masyarakat untuk mengembangkan keterampilan dan pengetahuan, sebagai suatu langkah untuk mengimbangi akan perkembangan tersebut pada lembaga pendidikan khususnya pada tingkat sekolah dasar, terdapat beberapa mata pelajaran yang harus dipahami dan dikuasai oleh peserta didik, salah satu bagian dari mata pelajaran yang berkaitan dengan perubahan yang terjadi pada masyarakat adalah 
ilmu pengetahuan sosial (IPS). Karena IPS menurut Ahmadi (2011, hlm. 10) adalah "salah satu mata pelajaran yang diberikan di SD yang mengkaji seperangkat peristiwa, fakta, konsep, dan generalisasi yang berkaitan dengan isu sosial. Memuat materi geografi, sejarah, sosiologi, dan ekonomi. Melalui mata pelajaran IPS, anak diarahkan untuk dapat menjadi warga negara Indonesia yang demokratis, bertanggung jawab, serta warga dunia yang cinta damai."

Adapun ruang lingkup pembelajaran IPS menurut Rudi Gunawan (2011, hlm. 45) meliputi aspek-aspek sebagai berikut: 1) manusia, tempat dan lingkungan; 2) waktu, keberlanjutan dan perubahan; 3) sistem sosial dan budaya; 4) perilaku ekonomi dan kesejahteraan.

Mata pelaran IPS dalam kajian KTSP 2006 (Depdiknas 2006, hlm. 45) menjelaskan bahwa ilmu pengetahuan sosial bertujuan agar siswa memiliki kemampuan sebagai berikut:
1. Mengenal konsep-konsep yang berkaitan dengan kehidupan masyarakat dan lingkungannya.

2. Memiliki kemampuan dasar untuk berfikir logis, dan kritis, rasa ingin tahu, inkuiri, memecahkan masalah dan keterampilan dalam kehidupan sosial.

3. Memiliki komitmen dan kesadaran terhadap nilai-nilai sosial dan kemanusiaan.

4. Memiliki kemampuan dan kesadaran terhadap nilai-nilai sosial dan kemanusiaan.

5. Memiliki

kemampuan berkomunikasi, bekerja sama dan berkompetisi dalam masyarakat yang majemuk, di tingkat lokal, nasional dan global.

Atas dasar penjelasan IPS, ruang lingkup pembelajran IPS, dan tujuan pembelajaran IPS di atas, ternyata pembelajaran IPS dimaksudkan untuk membekali siswa agar memiliki kemampuan bersosialisasi, berkomunikasi, bekerjasama dan berkompetisi dalam masyarakat yang majemuk ditingkat lokal, nasional, dan 
gelobal. Selain itu pembelajaran IPS meliputi beberapa aspek diantaranya manusia, waktu, sistem sosial dan ekonomi kesejahteraan. Sesuai dengan tujuannya, hendaknya pembelajaran IPS di sekolah dasar lebih menekankan pada aktivitas manusia dalam berbagai dimensi kehidupan sosial sesuai dengan karakteristik manusia sebagai makhluk sosial.

Namun, pada kenyataannya teknik pengajaran pembelajaran IPS masih didominasi dengan menggunakan metode ceramah, dimana siswa hanya mendengarkan dan mencatat apa yang dijelaskan guru sehingga menyebabkan siswa menjadi kurang aktif dalam proses belajar yang secara tidak langsung berpengaruh terhadap motivasi belajar.

Oleh sebab itu, pelaksanaan pembelajaran IPS di sekolah dasar hendaknya bisa memberikan ketertarikan sehingga tidak ada lagi anggapan siswa terhadap pembelajaran IPS yang dianggap monoton dan membosankan, motivasi belajar siswa juga dapat meningkat hasil belajar peserta didik untuk mencapai kriteria ketuntasan minimal (KKM), selain itu tujuan dari mata pelajaran IPS dapat tercapai.

Berdasarkan data awal hasil observasi langsung kelapangan dan wawancara dengan guru di kelas V Sekolah Dasar Negeri Cikaret Cianjur Kecamatan Cikadu Kabupaten Cianjur Bapak Yuyun S.Pd hari kamis, tanggal 5 Februari 2015 jam 09.00 WIB (1). Guru masih menggunakan metode pembelajaran tradisional, (2). Kurangnya sumber dan bahan ajar yang variatif dalam proses pembelajaran (3). Kurangnya penggunaan media yang tepat sehingga proses pebelajaran tidak menarik (4). Pembelajaran cenderung kepada satu arah (teacher centered) sehingga pembelajaran kurang efektif. (5) Jumlah siswa 22 orang terdiri dari (13 orang siswa perempuan dan 9 orang siswa laki-laki) sehingga pembimbingan dan pengawasan kurang optimal (6). Keaktifan siswa paling tinggi pada saat 
proses pembelajaran berlangsung mencapai $31,9 \%$ (3 orang siswa laki-laki dan 4 orang siswa perempuan dari 22 siswa ), sedangkan keaktifan siswa sedang $27,2 \%$ ( 2 orang siswa laki-laki dan 4 orang siswa perempuan dari 22 siswa), dan sisanya siswa belum aktif $40,9 \%$ (4 orang siswa laki-laki dan 5 orang siswa perempuan dari 22 siswa).

Paparan di atas menjadi faktor utama yang membuat siswa menjadi kurang aktif, sehingga mempengaruhi hasil belajar siswa kurang optimal terhadap materi peninggaan sejarah keraajaan bdha di Indonesia.

Berdasarkan hasil wawancara dengan murid kelas $\mathrm{V}$ Sekolah Dasar Negeri Cikaret Cianjur, pada tanggal 5 Februari 2015 jam 10.20 sebagai berikut: (1). Siswa merasa kurang menyenangi pembelajaran IPS karena kurang dilibatkan secara aktif pada saat proses pembelajaran berlangsung (2). Penjelasan guru mengenai pembelajaran belum dapat dipahami oleh semua siswa. (3).
Motivasi siswa untuk bertanya masih rendah sehingga hasil belajar belum optimal.

Hal tersebut dibuktikan dengan daftar nlai hasil belajar siswa pada pembelajaran IPS dalam materi peninggalan sejarah kerajaan Budha di Indonesia kelas V SD Negeri Cikaret Kecamatan Cikadu Kabupaten Cianjur. Kriteria Ketuntasan Minimal (KKM) untuk mata pelajaran IPS adalah 70 , siswa yang memperoleh nilai di bawah KKM sebanyak 59,1\% (13 dari 22 orang siswa) sedangkan siswa yang memperoleh nilai di atas KKM sebanyak 40,9 \% ( 9 dari 22 orang siswa).

Dari paparan di atas, peneliti menyimpulkan bahwa salah satu yang mengakibatkan hasil belajar siswa belum memenuhi KKM antara lain tepatnya motivasi siswa untuk mengikuti proses pembelajaran, hal ini sesuai dengan hasil observasi di SD Negeri Cikaret Cianjur dapat dilihat bahwa siswa yang memiliki motivasi tinggi sebanyak 7 orang $(31,9 \%)$, siswa yang memiliki motivasi sedang 6 orang $(27,2$ 
\%) dan sisanya siswa memiliki motivasi rendah 9 orang (40,9\%). Oleh karena itu, motivasi memiliki pengaruh terhadap perilaku belajar siswa yaitu motivasi mendorong meningkatnya semangat dan ketekunan dalam belajar. Hamzah B. Uno, M.Pd (2014, hlm 1) motivasi adalah dorongan dasar yang menggerakan seseorang bertingkah laku. Dorongan ini berada pada diri seseorang yang menggerakan untuk melakukan sesuatu yang sesuai dengan dorongan dalam dirinya.

Sementara menurut Guay dalam Euis Karwati dan Donni Juni P (2014 , hlm. 165)

Motivacion refers to the reasons underlying behavior " (motivasi mengacu pada alasan yang mendasari perilaku). sedangkan menurut Vroom menyatakan bahwa motivasi mengacu kepada suatu proses mempengaruhi pilihan-pilihan individu terhadap bermacam-macam bentuk kegiatan yang dihadapi.

Dari pendapat di atas dapat disimpulkan bahwa motivasi adalah suatu dorongan dari diri seseorang yang mengacu kepada suatu proses mempengaruhi pilihan-pilihan individu terhadap bermacam-macam bentuk kegiatan yang dihadapi. Maka dapat diperoleh suatu kesimpulan bahwa motivasi belajar IPS di Sekolah Dasar berpengaruh terhadap hasil belajar. Puranto (2010, hlm. 46) hasil belajar adalah perubahan perilaku peserta didik akibat belajar. Perubahan perilaku disebabkan karena dia mencapai penguasaan atas sejumlah bahan yang diberikan dalam proses belajar mengajar.

Hasil belajar menurut Jukknis dan Unwin dalam buku Uno (2011, hlm. 17) "hasil belajar adalah pernyataan yang menunjukan tentang apa yang mungkin dikerjakan siswa sebagai hasil dari kegiatan belajarnya. Jadi hasil belajar merupakan pengalaman-pengalaman belajar yang diperoleh siswa dalam bentuk kemampuan-kemampuan tertentu".

Dari pendapat di atas dapat disimpulkan bahwa hasil belajar adalah perubahan prilaku peserta 
didik diakibatkan belajar dari pengalaman-pengalaman yang diperoleh siswa dalam bentuk kemampuan-kemampuan tertentu.

Melihat dari permasalahan di atas peniliti mengambil model Probem Based Learning untuk meningkatkan motivasi dan hasil belajar siswa kelas V SD Negeri Cikaret dengan pembelajaran IPS pada materi Peninggalan Sejarah Kerajaan Budha Di Indonesia.

Adapun Keungulan Problem Based Learning Menurut Warsono dan Hariyanto ( 2012, hlm. 152) antara lain:

1. Siswa

akan

terbiasa

menghadapi masalah (problem posing) dan tertantang untuk menyelesaikan masalah tidak hanya terkait dengan pembelajaran di kelas tetapi juga menghadapi masalah yang ada dalam kehidupan seharihari (real world).

2. Memupuk solidaritas sosial dengan terbiasa berdiskusi dengan teman-teman.

3. Makin mengakrabkan guru dengan siswa.
4. Membiasakan siswa melakukan eksperimen.

Dari beberapa kelebihan di atas maka saya merasa tertarik untuk menggunakan model tersebut karena mengacu kepada PAIKEM.

Salah satu alternatif model pembelajaran yang memungkinkan dikembangkannya keterampilan berpikir siswa (penalaran, komunikasi, dan koneksi) dalam memecahkan masaah adalah pembelajaran berbasis masalah. Menurut Tan dalam Rusman (2010, hlm. 229) Pembelajaran Berbasis Masalah merupakan inovasi dalam pembelajaran karena dalam PBM kemampuan berpikir siswa betulbetul dioptimalisasikan melalui proses kerja kelompok atau tim yang sistematis, sehingga siswa dapat memberdayakan, mengasah, menguji, dan mengembangkan kemampuan berpikirnya secara kesinambungan.

Sementara menurut Wena (2011, hlm. 91) PBL merupakan pembelajaran yang 
menghadapkan siswa pada permasalahan-permasalahan

praktis sebagai pijakan dalam belajar atau dengan kata lain siswa belajar melalui permasalahanpermasalahan.

Dari beberapa pendapat diatas dapat disimpulkan bahwa model pembelajaran Problem Based Learning adalah kegiatan pembelajaran dengan menghadapkan siswa pada permasalahan-permasalahan

dunia nyata untuk betul-betul dioptimalisasikan melalui proses kerja kelompok atau tim yang sistematis, sehingga siswa dapat memberdayakan, mengasah, menguji, dan mengembangkan kemampuan berpikirnya secara kesinambungan.

Alasan yang mendasari pemilihan model Problem Based Learning karena model ini lebih menarik untuk peserta didik dengan mencari solusi terhadap permaalahan yang diberikan oleh guru dan secara tidak langsung siswa akan berantusias atau aktif saat proses pembelajaraan berlangsung. Setelah mengikuti pembelajaran dengan menggunakan mode Problem Based Learning diharapkan dapat meningkatkan motivasi siswa dalam belajar sehingga hasil belajar siswa meningkat.

Menyadari akan manfaat model Problem Based Lerning $(P B L)$ serta melihat kenyataan bahwa model tersebut masih jarang dimanfaatkan dalam kelas maka perlu kiranya diadakan penelitian untuk mengetahui lebih lanjut adakah perbedaan hasil belajar IPS maka dari itu peneliti ingin meningkatkan segala kemampuan siswa dengan judul penelitian "Penerapan Model Problem Based Learning Untuk Meningkatkan Motivasi dan Hasil Belajar Siswa dengan Pembelajaran IImu Pengetahuan Sosial pada Materi Peninggalan Sejarah Kerajaan Budha Di Indonesia "

B. LANDASAN TEORI

1. Model Pembelajaran Problem Based Learning

\section{a. Model Pembelajaran}

Guru dituntut dapat memilih model pembelajaran yang dapat 
memacu semangat setiap siswa untuk secara aktif ikut terlibat dalam pengalaman belajarnya. Joyce \& Weil dalam Rusman (2010, hlm. 133 ) model pembelajaran adalah suatu rencana atau pola yang dapat digunakan untuk membentuk kurikulum (rencana pembelajaran jangka panjang), merancang bahan-bahan pembelajaran, dan membimbing pembelajaran atau yang lain.

Sementara Zubaidi (2011, hlm. 185) mengungkapkan bahwa model pembelajaran adalah bentuk pembelajaran yang tergambar dari awal sampai akhir yang disajikan secara khas oleh guru di kelas. Selanjutnya, pada pengembangan model pembelajaran menurut pandangan konstruktivis harus memperhatikan dan mempertimbangkan pengetahuan awal siswa yang mungkin diperoleh di luar sekolah serta dalam pembelajarannya harus melibatkan siswa dalam suatu kegiatan yang nyata Rustaman (2011, hlm. 217).
Berdasarkan pendapat di atas, peneliti menyimpulkan bahwa model pembelajaran adalah suatu rencana atau pola yang dapat digunakan untuk membentuk kurikulum (rencana pembelajaran jangka panjang), dan membentuk pembelajaran yang tergambar dari awal sampai akhir pembelajaran yang harus melibatkan siswa dalam suatu kegiatan nyata. Model pembelajaran dapat dijadikan pola piihan, artinya para guru boleh memilih model pembelajaran yang sesuai dan epektif untuk mencapai tujuan pendidikannya.

\section{b. Definisi Problem Based Learning \\ Model Problem Based Learning dikembangkan} berdasarkan konsep-konsep yang dicetuskan oleh Jerome Bruner. Konsep tersebut adalah belajar penemuan atau discovery learning. Konsep tersebut memberikan dukungan teoritis terhadap pengembangan model PBL yang berorientasi pada kecakapan memproses informasi.

Sementara Tan dalam Rusman (2010, hlm. 229) Problem 
Based Learning merupakan penggunaan berbagai macam kecerdasan yang diperlukan untuk melakukan konfrontasi terhadap tantangan dunia nyata, kemampuan untuk menghadapi segala sesuatu yang baru dan kompleksitas yang ada. Pendapat di atas diperjelas oleh Ibrahim dan Nur dalam Rusman (2010, hlm. 241) bahwa PBL merupakan suatu pendekatan pembelajaran yang digunakan untuk merangsang berpikir tingkat tinggi siswa dalam situasi yang berorientasi pada masalah dunia nyata, termasuk di dalamnya belajar bagaimana belajar. Seperti yang telah diungkapkan oleh pakar PBL Barrows (dalam gayahidupalami.wordpress.com, 2014) PBL merupakan sebuah model pembelajaran yang didasarkan pada prinsip bahwa masalah (problem) dapat digunakan sebagai titik awal untuk mendapatkan atau mengintegrasikan pengetahuan (knowledge) baru.

Model Problem Based Learning ialah proses kegiatan pembelajaran dengan cara menggunakan atau memnculkan masalah dunia nyata, sebagai bahan pemikiran bagi peserta didik dalam memecahkan masalah untuk memperoleh pengetahuan dari suatu materi pelajaran Sitiatava ( 2013, hlm. 66).

Berdasarkan pendapat di atas, peneliti menyimpulkan bahwa model Problem Based Learning adalah suatu proses pembelajaran yang digunakan untuk merangsang berpikir tingkat tinggi siswa, dalam situasi yang berorientasi pada masalah dunia nyata. Sebagai bahan pemikiran bagi peserta didik dalam memecahkan masalah untuk memperoleh pengetahuan dari suatu materi pembelajaran.

\section{c. Karakteristik Problem Based}

\section{Learning}

Secara umum, Problem Based Learning mempunyai karakteristik sebagai model pembelajaran yang menggunakan masalah dunia nyata sebagai suatu konteks bagi siswa untuk belajar tentang keterampilan peecahan masalah dan berfikir kritis untuk memperoleh 
pengetahuan dan konsep esensial. Hal ini sejalan dengan pendapat Rizema (2013, hlm. 72), menurutnya Probem Based Learning memiliki karakteristik sebagai berikut :

1) Belajar dimulai dengan satu masalah.

2) Memastikan bahwa masaah tersebut berhubungan dengan dunia nyata siswa.

3) Mengorganisasikan pelajaran seputar masalah, bukan disiplin ilmu.

4) Memberikan tanggung jawab besar kepada siswa dalam membentuk dan menjalankan secara langsung proses belajara.

5) Menggunakan kelompok kecil.

6) Menuntut siswa untuk mendemonstrasikan yang telah dipelajari daam bentuk produk atau kinerja.

Sedangkan karakteristik model Problem Based Learning menurut Rusman (2013, hlm. 232) adalah sebagai berikut:

1) Permasalahan menjadi starting point dalam belajar.
2) Permasalahan yang diangkat adalah permasalahan yang ada di dunia nyata yang tidak terstruktur.

3) Permasalahan membutuhkan perspektif ganda (multiple perspective).

4) Permasalahan menantang pengetahuan yang dimiliki oleh siswa, sikap, dan kompetensi yang kemudian membutuhkan identifikasi kebutuhan belajar dan bidang baru dalam belajar.

5) Belajar pengarahan diri menjadi hal yang utama.

6) Pemanfaatan sumber pengetahuan yang beragam, penggunaannya, dan evaluasi sumber informasi merupakan proses yang esensial dalam problem based learning.

7) Belajar adalah kolaboratif, komunikasi, dan kooperatif.

8) Pengembangan keterampilan inquiry dan pemecahan masalah sama pentingnya dengan penguasaan isi pengetahuan untuk mencari solusi dari sebuah permasalahan. 
9) Sintesis dan integrasi dari sebuah proses belajar.

10) Problem based learning melibatkan evaluasi dan review pengalaman siswa dan proses belajar.

Berdasarkan pendapat di atas, peneliti menyimpulkan bahwa karakteristik Problem Based Learning adalah sebagai berikut :

1) Belajar dimulai dengan satu masalah

2) Pembelajaran yang diangkat dari masalah nyata.

3) Menggunakan kelompok kecil.

4) Memecahkan masalah untuk mencari solusi dari permasalahan.

5) Evaluasi dan review pengalaman siswa dalam proses belajar.

d. Tujuan Model Problem Based Learning dalam

\section{PembSelajaran}

Setiap model pembelajaran memiliki tujuan yang ingin dicapai, seperti yang diungkapkan Rusman (2010, hlm. 238) bahwa tujuan model PBM adalah penguasaan isi belajar dari disiplin heuristik dan pengembangan keterampilan pemecahan masalah. Hal ini sesuai dengan karakteristik model PBL yaitu belajar tentang kehidupan yang lebih luas, keterampilan memaknai informasi, kolaboratif, dan belajar tim, serta kemampuan berpikir reflektif dan evaluatif.

Sedangkan menurut Ibrahim dan Nur dalam Rusman (2010, hlm. 242) mengemukakan tujuan model PBL secara lebih rinci yaitu: (a) membantu siswa mengembangkan kemampuan berpikir dan memecahkan masalah; (b) belajar berbagai peran orang dewasa melalui keterlibatan mereka dalam pengalaman nyata dan; menjadi para siswa yang otonom atau mandiri.

Berdasarkan pendapat di atas, peneliti menyimpulkan bahwa tujuan model pembelajaran Problem Based Learning adalah (a) membantu siswa mengembangkan kemampuan berfikir dan memecahkan masalah. (b) belajar tentang kehidupan yang lebih luas. (c) belajar tim atau 
secara berkelompok. (d). menjadi siswa yang lebih mandiir.

\section{e. Langkah-langkah Model}

Problem Based Learning Model Problem Based Learning memiliki beberapa tahapan pada implementasinya dalam proses pembelajaran. Tahapan pembelajaran yang diusulkan untuk dilakukan dengan model Probem Based Learning. Ridwan Abdul Sani ( 2014, hlm. 153-154) adalah sebaga berikut:

1) Guru menyampaikan permasalahan kepada siswa atau siswa mengajukan permasalahn yang relevan dengan topk yang akan dikaji. Permasalahan yang diajukan merupakan permasaahan kompleks yang kurang terstruktur dan terkait dengan situasi nyata atau kontekstual. Problem yan disajikan harus dapat ditelaah melalui inkuiri bebas dan mengembnagkan kemampuan siswa untuk menyelesaikan masalah.

2) Siswa mendiksusikan permasalahan dalam kelompok kecil. Kelompok mengkarifikasi fakta dan mencari hubungan konsep yang relevan. Anggota kelopok melakuka curah pendapat berdasarkan pengetahuan awa mereka dalam upaya memahami permasalahan dan mengajukan usulan solusi. Kelopok mengidentifikasi hal-hal yang belum mereka pahami dan perlu dipelajari untuk menyelesaikan masalah.

3) Siswa atau kelompok membuat perencanaan untuk menyelesaikan permasalah. Anggota kelompok berbagi peran untuk mempelajari fakta dan konsep atau mempersiapkan kegiatan eksplorasi.

4) Masing-maisng siswa melakukan penelusuran informasi atau observas berdasarkan tugas yang yelah ditetapkan dalam dskusi kelompok. Data atau informasi dapat diperoleh melalui perpustakaan, internet, pengamatan, wawancara, dan sumber lainnya. 
5) Siswa kembai melakukan diskusi kelompok dan berbagi inforasi. Informasi atau pengethauan yang diperoleh digunakan untuk menyelesaikan permasalahan yang dikaji. Kerja kelompok dapat dilakukan di kelas dalam bentuk diskusi kelompok terfokus ( focus group discussion atau FGD).

6) Kelompok menyajikan solusi permasalahan kepada teman sekelas. Penyajian solusi permasalahan harus dilakukan dipersiapkan terlebih dahuu dan sebaiknya menggunaka teknologi informasi. Teman lainmenanggapi hasil kerja yang ditayangkan.

7) Anggota kelompok melakukan pengkajian ulang (review) terhadap proses penyelesaian masalah yang telah dilakukan dan menilai konstribusi dari masing-masing anggota. Proses penilaian diri dan teman sejawat dapat dilakukan pad atahap akhir sebagai motede refleksi bagi keompok dan metode penilaian bagi guru.
Tahapan

pembelajaran dengan strategi Problem Based Learning . Mohamad Nur dalam Rusmono (2014, hlm. 81) adalah sebagai berikut :

\begin{tabular}{|c|c|}
\hline $\begin{array}{c}\text { Tahapan } \\
\text { Pembelajaran }\end{array}$ & Perilaku Guru \\
\hline $\begin{array}{l}\text { Tahap 1: } \\
\text { Mengorganisasi } \\
\text { kan siswa } \\
\text { kepada } \\
\text { masalah. }\end{array}$ & $\begin{array}{l}\text { Guru } \\
\text { menginformasi } \\
\text { kan tujuan- } \\
\text { tujuan } \\
\text { pembelajaran, } \\
\text { mendeskripsik } \\
\text { an kebutuhan- } \\
\text { kebutuhan } \\
\text { logistik penting, } \\
\text { dan } \\
\text { memotivasi } \\
\text { siswa agar } \\
\text { teribat dalam } \\
\text { kegiatan } \\
\text { pemecahan } \\
\text { masalah yang } \\
\text { mereka piih } \\
\text { sendiri. }\end{array}$ \\
\hline $\begin{array}{l}\text { Tahap } 2 \text { : } \\
\text { Mengorganisasi } \\
\text { kan siswa untuk } \\
\text { belajar. }\end{array}$ & $\begin{array}{l}\text { Guru } \\
\text { membantu } \\
\text { siswa } \\
\text { menentukan }\end{array}$ \\
\hline
\end{tabular}




\begin{tabular}{|c|c|}
\hline $\begin{array}{c}\text { Tahapan } \\
\text { Pembelaiaran }\end{array}$ & Perilaku Guru \\
\hline & $\begin{array}{l}\text { dan mengatur } \\
\text { tugas-tugas } \\
\text { belajar yang } \\
\text { berhubungan } \\
\text { dengan } \\
\text { masalah itu. }\end{array}$ \\
\hline $\begin{array}{l}\text { Tahap 3: } \\
\text { Membantu } \\
\text { penyelidikan } \\
\text { mandiri dan } \\
\text { kelompok. }\end{array}$ & $\begin{array}{l}\text { Guru } \\
\text { mendorong } \\
\text { siswa } \\
\text { mengumpulkan } \\
\text { informasi yang } \\
\text { sesuai, } \\
\text { melaksanaka } \\
\text { eksperimen, } \\
\text { mencari } \\
\text { penjelasan, } \\
\text { dan solusi. }\end{array}$ \\
\hline $\begin{array}{l}\text { Tahap } 4 \text { : } \\
\text { Mengembangka } \\
n \quad \text { dan } \\
\text { mempersentasik } \\
\text { an hasil karya } \\
\text { serta pameran. }\end{array}$ & $\begin{array}{l}\text { Guru } \\
\text { membantu } \\
\text { siswa dalam } \\
\text { merencanakan } \\
\text { dan } \\
\text { menyiapkan } \\
\text { hasil karya } \\
\text { yang sesuai } \\
\text { seperti laporan, } \\
\text { rekaman, } \\
\text { video, dan }\end{array}$ \\
\hline
\end{tabular}

\begin{tabular}{|c|c|}
\hline $\begin{array}{c}\text { Tahapan } \\
\text { Pembelaiaran }\end{array}$ & Perilaku Guru \\
\hline & $\begin{array}{l}\text { modelm serta } \\
\text { membantu } \\
\text { mereka } \\
\text { berbagi karya } \\
\text { mereka. }\end{array}$ \\
\hline $\begin{array}{l}\text { Tahap } 5 \text { : } \\
\text { Menganalisis } \\
\text { dan } \\
\text { mengevaluasi } \\
\text { proses } \\
\text { pemecahan } \\
\text { masalah. }\end{array}$ & $\begin{array}{l}\text { Guru } \\
\text { membantu } \\
\text { siswa } \\
\text { melakukan } \\
\text { refleksi atas } \\
\text { penyelidikan } \\
\text { dap roses- } \\
\text { proses yang } \\
\text { mereka } \\
\text { gunakan. }\end{array}$ \\
\hline
\end{tabular}

\section{f. Kelebihan dan Kekurangan} Model Problem Based

\section{Learning}

Setiap model pembelajaran memiliki kelebihan dan kekurangan, sebagaimana model PBL juga memiliki kelemahan dan kelebihan yang perlu dicermati untuk keberhasilan penggunaannya. Warsono dan Hariyanto, (2012, hlm. 152) kelebihan PBL antara lain: 
1) Siswa akan terbiasa menghadapi masalah (problem posing) dan tertantang untuk menyelesaikan masalah tidak hanya terkait dengan pembelajaran di kelas tetapi juga menghadapi masalah yang ada dalam kehidupan seharihari (real world).

2) Memupuk solidaritas sosial dengan terbiasa berdiskusi dengan teman-teman.

3) Makin mengakrabkan guru dengan siswa.

4) Membiasakan siswa melakukan eksperimen.

Kelemahan dari penerapan model ini antara lain:

1) Tidak banyak guru yang mampu mengantarkan siswa kepada pemecahan masalah.

2) Seringkali memerlukan biaya yang mahal dan waktu yang panjang.

3) Aktivitas siswa di luar sekolah sulit dipantau.

\section{Motivasi Belajar}

\section{a. Pengertian Motivasi Belajar}

Motivasi merupakan salah satu aspek psikis yang memiliki pengaruh terhadap pencapaian prestasi belajar. Dalam psikologi, istilah motif sering dibedakan dengan istilah motivasi. Kata "motif" diartikan sebagai daya upaya yang mendorong seseorang untuk melakukan sesuatu (Sardiman, 2011, hlm 73). Sedangkan menurut Mc. Donald dalam Sardiman (2011, hlm 73) motivasi adalah perubahan energi dalam diri seseorang yang ditandai dengan munculnya "feeling" dan didahului dengan tanggapan terhadap adanya tujuan.

Selanjutnya menurut

B. Hamzah Uno (2014, hlm. 1) Istilah motivasi berasal dari kata motif yang dapat diartikan sebagi kekuatan yang terdapat daam diri individu, yang menyebabkan individu tersebut bertindak atau berbuat. Motif tidak dpaat diamati secara angsung, tetapi dapat diinterprestasikan daam tingkah lakunya, berupa rangsangan, dorongan, atau pembangkit tenaga munculnya suatu tingkah laku tertentu.

Motivasi adalah dorongan dasar yang menggerakan seseorang bertingkah laku. 
Dorongan ini berada pada diri seseorang yang menggerakan untuk melakukan sesuatu yang sesuai dengan dorongan dalam dirinya. Oleh Karena itu, perbuatan seseorang didasarkan atas motivasi tertentu mengandung tema sesuai dengan motivasi yang mendasarinya. Motivasi juga dapat dikatakan sebagai perbedaan antara dapat melaksanakn dan mau melaksanakan. Motivasi lebih dekat pada mau melaksanakan tugas untuk mencapai tujuan. Motivasi adaah kekuatan, baik drai daam maupun drai luar yang mendorong seseorang untuk mencapai tujuan tertentu yang telah ditetapkan sebelumnya. Atau dengan kata lain, motivasi dapat diartikan sebagai dorongan mental terhadap perorangan atau orangorang sebagi anggota masyarakat. Motivasi dapat juga diartikan sebagi proses untuk mencoba mempengaruhi orang atau orangorang yang dipimpinya agar melakukan pekerjaan yang diinginkan, sesuai dengan tujuan tertentu yang ditetapkan lebih dahulu. B Hamzah Uno (2014, hlm. 1)

Berdasarkan pendapat di atas, peneliti menyimpulkan bahwa motivasi adalah dorongan dasar yang menggerakan seseorang bertingkah laku dan adanya perubahan dari energy dalam diri untuk mencapai tujuan tertentu yang telah ditetapkan sebelumnya.

\section{b. Jenis Motivasi}

Berikut ini merupakan jenisjenis dari motivasi menenurt Nanang \& Cucu (2012, hlm. 26-27 ) diantaranta :

1) Motivasi intrinsik, yaitu motivasi yang datangnya secara alamiah atau murni dari diri siswa itu sendri sebagai wujud adanya kesadaran diri (sef awareness) dari lubuk hati yang paling dalam.

2) Motivasi ekstrinsik adalah motivasi yang datangnya disebabkan faktor-faktor di luar dari siswa, seperti adanya pemberian nasihat dari gurunya, hadiah (reward), kompetisi sehat antar peserta didik, 
hukuman (funishment), dan menerima ganjaran atau sebagainya

menghindari hukuman.

Sementara menurut Hamzah.

\section{c. Fungsi Motivasi}

B. Uno (2014, hlm. 7 ) motivasi

Setiap aktivitas yang intrinsik, yaitu motivasi yang muncul dari dalam seperti minat atau keinginan (curiocity, sehingga seseorang tidak lagi termotivasi oleh bentuk-bentuk insentif atau hukuman. Sementara motivasi ekstrinsik ialah motivasi yang disebabkan oleh keinginan untuk menerima ganjaran atau menghindari hukuman, motivasi yang terbentuk oleh faktor-faktor eksternal berupa ganjaran atau hukuman.

Berdasarkan pendapat di atas, peneliti menyimpulkan bahwa motivasi memiliki dua jenis yaitu motivasi intrinsik dan motivasi ekstrinsik. Motivasi intrinsik yaitu motivasi yang datang secara alamiah atau murni dari diri siswa. seperti minat atau keinginan (curiocity, sehingga seseorang tidak lagi termotivasi oleh bentukbentuk insentif atau hukuman. Sedangkan motivasi ektrinsik adalah motivasi yang disebabkan dari faktor luar diri siswa, untuk dilaksanakan oleh siswa, tidak terlepas daria danya faktor motivasi, dimana motivasi tersebut erat kaitaanya dengan tujuan. Berikut ini merupakan beberapa fungsi dari motivasi menurut Oemar Malik (2011, hlm. 160 ) meliputi:

1) Mendorong timbulnya kelakuan atau suatu perbuatan. Tanpa motivasi maka tidak akan timbul sesuatu perbuatan seperti belajar motivasi berfungsi sebagai pengarah. Artinya mengarahkan perbuatan kepencapaian tujuan yang diinginkan

2) Motivasi berfungsi sebagai penggerak. la berfungsi sebagai mesin bagi mobil. Besar kecinya motivasi menentukan cepat atau lambatnya suatu pekerjaan.

Berdasarkan pendapat di atas, peneliti menyimpulkan bahwa fungsi motivasi meliputi : 
1) Motivasi merupakan alat pendorong timbulnya belajar untuk siswa.

2) Motivasi berfungsi sebagai penggerak untuk mempengaruhi prestasi belajar siswa.

3) Motivasi merupakan alat untuk membangun system pembelajaran lebih bermakna.

\section{d. Karakteristik Motivasi Belajar}

Motivasi belajar, pada umumnya memiliki beberapa indikator atau unsur yang mempunyai peranan besar dalam keberhasilan seseorang dalam belajar. Sardiman (2011, hlm. 83) menyatakan motivasi yang ada pada diri setiap orang itu memiliki ciri-ciri sebagai berikut:

1) Tekun menghadapi tugas (dapat bekerja terus-menerus dalam waktu lama, tidak berhenti sebelum selesai)

2) Ulet menghadapi kesulitan (tidak lekas putus asa). Tidak memerlukan dorongan dari luar untuk berprestasi sebaik mungkin (tidak cepat puas dengan prestasi yang telah dicapainya)
3) Menunjukkan minat terhadap macam-macam masalah "untuk orang dewasa" (misalnya masalah pembangunan agama, politik, ekonomi, keadilan, pemberantasan korupsi, dan sebagainya)

4) Lebih senang bekerja mandiri

5) Cepat bosan pada tugas-tugas yang rutin (hal-hal yang bersifat mekanis,berulang-ulang begitu saja, sehingga kurang kreatif)

6) Dapat mempertahankan pendapatnya (kalau sudah yakin akan sesuatu)

7) Tidak mudah melepaskan hal yang diyakini itu

8) Senang mencari dan memecahkan masalah soalsoal.

\section{e. Sumber Motivasi Siswa}

Teori motivasi yang lazim digunakan untuk menjelaskan sumber motivasi peserta didik sedikitnya bisa digolongkan menjadi dua. Menrut Euis dan Donni (2014, hlm. 168) yaitu :

1. Motivasi intrinsik ( rangsangan dari dalam peserta didik )

Motivasi intrinsik adalah motivasi motif-motif yang menjadi 
aktif atau berfungsi tidak perlu dirangsnag dari luar, karena dalam dirinya berfungsi tidak perlu dirangsnag dari luar, karena dalam dirinya setiap siswa sudah ada dorongan untuk melakukan sesuatu. Itulah sebabnya motivais intrinsic dapat dapat juga dikatakan sebagai bentuk motivasi yang di dalamnya aktivitas dimulai dan diteruskan berdasarkan suatu doorngan dari daam diri dan secara mutlak berkait dengan aktivitas belajarnya. Faktor individual yang biasanya mendorong seseorang untuk melakukan sesuatu adalah :

a. Minat

Siswa akan merasa terdorong untuk belajar, jika kegiatan belajara tersebut sesuai dengan minatnya.

b. Sikap positif

Siswa yang mempunyai sifat positif terhadap suatu kegiatan, maka ia akan berusaha sebisa mungkin menyelesaikan kegiatan tersebut dengan sebaik-baiknya.

c. Kebutuhan
Siswa mempunyai kebutuhan tertentu da akan berusaha melakukan kegiatan apapun sesuai kebutuhannya.

2. Motivasi ekstrinsik (rangsangan dari luar diri siswa)

Motivasi ektrinsik adalah motif-motif yang aktif dan berfungsinya karena adanya perangsnag dari luar. Motivasi ekstrinsik dapat juga dikatakan sebagai bentuk motivasi yang di dalamnya aktivitas dimulai dan diteruskan berdasarkan dorongan dari luar yang tidak berkaitan dengan dirinya. Jenis motivasi ekstrinsik ini timbul sebagai akibat pengaruh dari luar peserta didik, apakah karena adanya ajakan, suruhan, atau paksaan dari orang lain, sehingga dengan keadaan demikian maka siswa mau melakuaknsesuatu, contohnya belajar. Bagi siswa dengan motivasi ekstrinsik yang lemah, misalnya rasa ingin tahunya, maka motivasi jenis kedua ini peru untuk diberikan.

Berdasarkan pendapat di atas, peneliti menyimpulkan bahwa fungsi motivasi memiliki dua fungsi 
yaitu motivasi intrisnik (rangsangan dari dalam peserta didik) yang meliputi : minat, sikap positif, dan kebutuhan sedangkan motivasi ekstrinsik (rangsangan dari luar diri siswa ) contohnya belajar. Bagi siswa dengan motivasi ekstrinsik yang lemah, misalnya rasa ingin tahunya.

\section{Hasil Belajar}

\section{a. Pengertian Hasil Beajar}

Belajar merupakan proses yang berkesinambungan hal ini dikarenakan ilmu pengetahuan yang terus serta kemampuan teknologi. Dalam sebuah pembelajaran tentu yang diharapkan adalah hasil belajar yang baik. Maka sebuah pembelajaran, hasil belajar merupakan ha yang penting. Dimiyati dan Mudjiono dalam Resty Anggarian (2010, hlm. 12). Hasil belajar merupakan hal yang dapat dipandang dari dua sisi yaitu sisi siswa dan sisi guru. Dari sisi siswa, hasil belajar merupakan tingkat perkembangan mental yang lebih baik dibandingkan pada saat belum belajar, tingkat perkembangan menta tersebut terwujud pda jenis ranah kognitif, afektif, dan psikomotor. Sedangkan dari sisi guru hasil belajar merupakan saat terselesaikannya bahan pelajaran.

SementaramOemar Hamalik dalam Resti Anggrian (2010, hlm 12) mengungkapkan bahwa hasil belajar adalah bila seseorang telah belajar akan terjadi perubahan tingkah laku pada orang tersebut, misalnya dari tidak tahu menjadi tahu, dan dari tidak mengerti jadi mengerti. Penjelasan Bloom dalam Sudjana, ( 2012, hlm. 22 -23 ), membagi hasil belajar atas tiga ranah yaitu ranah kognitif, ranah afektif, dan ranah psikomotor.

1) Ranah kognitif berkenaan dengan hasil belajar intelektual yang terdiri dari enam aspek, yakni pengetahuan atau ingatan, pemahaman, aplikasi, analisis, sintesis, dan evaluasi. Kedua aspek pertama disebut kognitif tingkat rendah dan keempat aspek berikutnya termasuk kognitif tingkat tinggi.

2) Ranah afektif berkenaaan dengan sikap yang terdiri dari lima aspek, yakni penerimaan, 
jawaban atau reaksi, penilaian, organisai, dan ternalisasi.

3) Ranah psikomotorik berkenaan dengan hasil belajar keterampilan dan kemampuan bertindak. Ada enam aspek ranah psikomotoris, yakni (a) gerakan refleks, keterampilan gerakan dasar, (c) kemampuan perseptual, (d) keharmonisan atau ketepatan, (e) gerakan keterampilan kompleks, dan (f) gerakan ekspresif dan interpretative.

Berdasarkan pendapat di atas, peneliti menyimpulkan bahwa hasil belajar merupakan proses tingkah laku yang diperoleh seseorang yang terwujud dalam ranah kognitif, apektif dan psikomotor. Hasil belajar sangat penting, selain bisa membuat siswa lebih terpacu, bias juga dapat membantu guru sejauh mana siswa dapat memahami pembelajaran.

\section{b. Karakteristik Hasil Belajar}

Ciri-ciri perubahan dalam pengertian belajar menurut Slameto dalam Fathurrohman dan Sutikno, (2010, hlm. 10) meliputi:
1) Perubahan yang terjadi berlangsung secara sadar, sekurang-kurangnya sadar bahwa pengetahuannya bertambah, sikapnya berubah, kecakapannya berkembang, dan lain-lain.

2) Perubahan dalam belajar bersifat kontinyu dan fungsional. Belajar bukan proses yang statis karena terus berkembang secara gradual dan setiap hasil belajar memiliki makna dan guna yang praktis.

3) Perubahan belajar bersifat positif dan aktif. Belajar senantiasa menuju perubahan yang lebih baik.

4) Perubahan dalam belajar bukan bersifat sementara, bukan hasil belajar jika perubahan itu hanya sesaat, seperti berkeringat, bersin, dan lain-lain.

5) Perubahan dalam belajar bertujuan dan terarah. Sebelum belajar, seseorang hendaknya sudah menyadari apa yang akan berubah pada dirinya melalui belajar.

6) Perubahan mencakup seluruh aspek tingkah laku, bukan 
bagian-bagian tertentu secara parsial.

Selain itu, menurut

Sugihartono (2011, hlm. 13) terdapat beberapa ciri-ciri belajar yaitu, antara lain:

1) Perubahan tingkah laku terjadi secara sadar;

2) Perubahan bersifat kontinu dan fungsional;

3) Perubahan bersifat aktif dan positif;

4) Perubahan bersifat permanen

5) Perubahandalam belajar bertujuan dan terarah; dan

6) Perubahan mencakup aspek tingkah laku

Ciri-ciri hasil belajar menurut Syaiful Bahri Djamarah (2011, hlm. 15-16) ditandai dengan berbagai perubahan antara lain sebagai beriukut :

1) Perubahan yang terjadi secara sadar

Individu yang belajar akan menyadari terjadinya perubahan itu sekurang-kurangnya individu merasakan telah terjadi adanya suatu perubahan dalam dirinya.

2) Perubahan dalam belajar bersifat fungsional
Perubahan yang terjadi dalam diri individu berlangsung terus menerus dan tidak statis. Suatu perubahan yang terjadi akan 14 menyebabkan perubahan berikutnya dan akan berguna bagi kehidupan atau proses belajar berikutnya.

3) Perubahan dalam belajar bersifat positif dan aktif

Perubahan itu selalu bertambah dan tertuju untuk memperoleh suatu yang lebih baik dari sebelumnya. Dengan demikian, makin banyak usaha belajar yang dilakukan, makin banyak dan makin baik perubahan yang diperoleh.

4) Perubahan dalam belajar bukan bersifat sementara

Perubahan yang terjadi karena proses belajar bersifat menetap atau permanen. Berarti tingkah laku yang terjadi setelah belajar bersifat menetap.

5) Perubahan dalam belajar bertujuan atau terarah

Berarti perubahan tingkah laku terjadi karena ada tujuan yang akan dicapai. Perubahan tingkah laku ini benar-benar disadari. 
6) Perubahan mencakup seluruh aspek tingkah laku

Jika seseorang belajar sesuatu, sebagai hasilnya ia akan mengalami perubahan tingkah laku secara menyeluruh dalam sikap, kebiasaan, keterampilan, pengetahuan, dan sebagainya. Berdasarkan pendapat di atas, peneliti menyimpulkan bahwa karakteristik atau ciri-ciri dari hasil belajar adalah sebagai berikut :

1) Perubahan tingkah laku terjadi secara sadar;

2) Perubahan bersifat kontinu dan fungsional;

3) Perubahan bersifat aktif dan positif;

4) Perubahan bersifat permanen

5) Perubahandalam belajar bertujuan dan terarah; dan

6) Perubahan mencakup seluruh aspek tingkah laku

\section{c. Penilaian Hasil Belajar}

Penilaian adalah tindak lanjut dari hasil pembelajaran yang telah dilakukan. Untuk itu penilaian hasil belajar sangat penting. Penilaian adalah proses memberikan atau menentukan nilai kepada objek tertentu berdasarkan suatu kriteria tertentu. Nana Sudjana (2010, hlm. 3). Dari pengertian tersebut, hasil belajar siswa dapat dikatakan sebagi objek dari penilain itu sendiri.

Berdasrkan pendapat di atas, peneliti menyimpulkan bahwa penilain hasil belajar adalah proses memberikan atau menentukan nilai kepada objek tertentu berdasarkan kriretia yang telah didapatkan dari penilaian itu sendiri.

Semetara itu penilain memiliki beberapa fungsi menurut Nana Sudjana (2010, hlm. 3) yaitu : Alat untuk mengetahui tercapai tidaknya tujuan intruksional. Dengan fungsi ini maka penilaian harus mengacu kepada rumusanrumusan tujuan intruksional.

1) Umpan balik bagi perbaikan proses belajar mengajar. Perbaikan mungkin dilakukan dalam hal tujuan intruksional, kegiatan belajar siswa, strategi mengajar guru dll.

2) Dasar dalam menyusun laporan kemajuan belajar siswa kepada orang tuanya. Daam aporan tersebut dikemukakan kemampuan dan kecakapan 
belajar siswa dalam berbaga

bidang studi dalam bentuk nilai-

nilai prestasi yang dicapainya.

\section{f. Tife Hasil Belajar}

Tipe hasil belajar menurut Nana Sudjana (2010, hlm. 22) menyatakan bahwa tujuan pendidikan yang ingin dicapai dalam suatu pengajaran terdiri dari 3 macam yaitu: ranah kognitif, afektif, dan psikomotor. Ketiga aspek tersebut merupakan suatu kesatuan yang tidak terpisahkan yang harus nampak sebagi hasil belajar.

Sebagimana disebutkan di atas, maka unsur-unsur yang terdapat dalam ketiga aspek pengajaran tersebut adalah sebagai berikut:

\section{1) Ranah kognitif}

Tipe hasil belajar ranah kognitif ini terbagi menjadi 6 poin, yaitu tipe hasil belajar sebagai berikut:

a) Pengetahuan

hafalan

(Knowledge), yaitu pengetahuan yang sifatnya faktual.

Merupakan jembatan untuk mengauassai tipe hasil belajar lainnya b) Pemahaman (Comprehention), yaitu kemampuan menangkap makna atau arti dari suatu konsep

c) Penerapan (Aplikasi), yaitu kesanggupan menerapkan dan mengabtrasikan suatu konsep, ide, rumus, hukum dalam situasi yang baru, misalnya memecahkan persoalan dengan menggunakan rumus tertentu

d) Analisis, yaitu kesanggupan memecahkan, menguasai suatu integritas (kesatuan yang utuh) menjadi unsur atau bagian yang mempunyai arti

e) Sintesis, yaitu kesanggupan menyatukan unsur atau bagian menjadi satu integritas

f) Evaluasi, yaitu kesanggupan memberikan keputusan tentang nilai sesuatu berdasarkan pendapat yang dimilikinya dan kriteria yang dipakainya.

\section{2) Ranah Apektif}

Tipe hasil belajar ranah afektif disini berkenaan dengan sikap. Hal ini kurang diperhatikan oleh guru, yang lebih menakankan pada bidang kognitif. Hal ini didasarkan pada pendapatb 
beberapa ahli yang mengatakan bahwa sikap seseorangdapat diramalkan perubahannya, bila seseorang telah menguasai bidang kognitif tingkat tinggi. Beberapa tingkatan bidang afektif sebaagai tujuan dan tipe hasil belajar siswa dari yang sederhana ke yang lebih komplek, yaitu:

a) Reciving atau attending, yakni semacam kepekaan dalam menerima rangsangan (stimulus) dari luar yang datang kepada siswa, baik dalam bentuk masalah, situasi, dan gejala

b) Reaponding atau jawaban, yakni reaksi yang diberikan oleh seseorang terhadap stimulasi yang datang dari luar

c) Valuting atau penilaian, yakni berhubungan dengan nilai dan kepercayaan terhadap gejala atau stimulus tadi

d) Organisasi, yakni pengembangan dari nilai ke dalam satu sistem organisasi, termasuk menentukan hubungan satu nilai dengan nilai lainnya, pemantapan, dan prioritas nilai yang telah dimilikinya.

e) Karakteristik nilai atau internalisasi nilai, yakni keterpaduan dari semua sistem nilai yang telah dimiliki seseorang, yang mempengaruhi pola kepribadian dan tingkah lakunya

\section{3) Ranah Psikomotor}

Tipe hasil belajar bidang psikomotor ini tampak dalam bentuk ketempilan (skill) dan kemampuan bertindak individu. Ada 6 tingkatan keterampilan tersebut, yaitu:

a) Gerakan refleks, yaitu keterampilan pada gerakan yang tidak sadar

b) Keterampilan pada gerakangerakan tidak sadar

c) Kemampuan perseptual, termasuk didalamnya membedakan visual, auditif, motoris, dan lain-lain

d) Kemampuan bidang fisik, misalnya kekuatan, keharmonisan dan ketepatan.

e) Gerakan-gerakan skill, mulai dari keterampilan sederhana 
sampai pada keterampilan yang kompleks

f) Kemampuan yang bekenaan dengan komunikasi nondecurvise, seperti gerakan ekspresi dan interpretatif.

Berdasarkan pendapat di atas, peneliti menyimpulkan bahwa tipe hasil belajar itu mempunya tujuan pendidikan yang ingin dicapai dalam suatu pengajaran terdiri dari 3 macam yaitu: ranah kognitif, afektif, dan psikomotor.

d. Kaitan Model Probem Based Learning dengan Motivasi dan Hasil Belajar.

Model pembelajaran Problem Based Learning adalah suatu proses pembelajaran yang digunakan untuk merangsang berpikir tingkat tinggi siswa, dalam situasi yang berorientasi pada masalah dunia nyata. Sebagai bahan pemikiran bagi peserta didik dalam memecahkan masalah untuk memperoleh pengetahuan dari suatu materi pelajaran. Ibrahim dan Nur dalam Rusman (2010, hlm. 241) bahwa Problem Based Learning merupakan suatu pendekatan pembelajaran yang digunakan untuk merangsang berpikir tingkat tinggi siswa dalam situasi yang berorientasi pada masalah dunia nyata, termasuk di dalamnya belajar bagaimana belajar.

Sementara menurut Noffit dalam Rusman (2010, hlm. 241) mengemukakan bahwa Pembelajaran Berbasis Masalah merupakan suatu pendekatan pembelajaran yang menggunakan masalah dunia nyata sebagai suatu konteks bagi siswa untuk belajar tentang berpikir kritis dan keterampilan pemecahan masalah serta untuk memperoleh pengetahuan dan konsep yang esensi dari materi pelajaran.

Seperti yang dijelaskan di atas, maka dapat disimpulkan bahwa dalam proses pembelajaran berbasis masalah peserta didik dituntut untuk memecahkan masalah dengan temen sekelompoknya sesuai dengan masalah yang diberikan oleh guru, model ini akan melatih aktivitas siswa untuk berfikir kritis dalam waktu yang cepat. Maka dapat 
dikatakan bahwa model pembelajaran Problem Based Learning adalah sebuah model pembelajaraan yang dalam prosesnya diberikan sebuah masalah, sehingga siswa untuk lebih aktif sebagai peningkatan hasil belajar. Siswa diharapakan memiliki kemampuan berinteraksi dan bersosialisasi sehingga siswa dapat terlibat secara aktif daam proses kegiatan belajar.

\section{METODE PENELITIAN}

Penelitian yang digunakan dalam penelitian ini adalah model penelitian tindakan kelas (PTK) atau Classroom action reasrch. Menurut Wiraatmatmadja dalam Eusi dan Donni (2014, hlm. 291) menyatakan bahwa PTK adalah bagaimana sekelompok guru dapat mengorganisasikan kondisi pihak praktikan pembelajaran mereka dan belajar dari pengalaman sendiri. Mereka dapat mencoba sebuah gagasan perbaikan dalam praktek pembelajaran, dan melihat pengaruh nyata dari upaya perbaikan tersebut.
Berdasarkan pengertian di atas, peneliti menyimpulkan bahwa yang dimaksud dengan Peneitian Tindakan Kelas (PTK) adalah sebuah penelitian yang dilakukan terhadap perilaku atau tindakan yang muncul di dalam proses pembelajaran yang berlangsung di dalam kelas. PTK dilaksanakan sebagai usaha untuk meningkatkan kualitas pembelajaran yang dilakukan guru di kelas, serta untuk memahami aspek-aspek yang berkenaan dengan siswa dan lingkungan yang ada disekitar kelas. PTK tidak akan mengganggu proses pembelajaran, karena dilakukan dalam proses pembelajaran yang alami di kelas, sesuai dengan jadwal pelajaran. PTK bersifat situasional, kontekstual, berskla kecil, dan secara relevan langsung berhubungan dengan situasi nyata di dalam kelas.

Model yang dikembangkan oleh Stepan Kemmis dan Robbin McTargert merupakan pengembangan dari model Kurt Lewin, sehingga terlihat mirip dengan model Lewin. Komponen 
tindakan (acting) dengan pengamatan (ovserving) disatukan dengan alasan kedua kegiatan itu tidak dapat dipisahkan satu sama lain, karena dilakukan dalam suatu kesatuan waktu.

Setiap tindakan dimulai dengan tahap rencana, di mana peneliti menyusun rencana pembelajaran, dan menyusun instrumen penelitian. Kemudian rencana yang telah disusun tersebut dilaksanakan pada tahap pelaksanaan. Selama pelaksanaan tindakan dilakukan observasi terhadap peneliti dan siswa terekam dalam lembar instrumen. Selanjutnya pada tahap refleksi, peneliti dan observer menganalisis proses pembelajaran dan perilaku siswa maupun peneliti. Dalam penelitian ini. Peneliti menyusun serangkaian tindakan dalam bentuk siklus. Untuk memperoleh hasil yang diinginkan, maka system pelaksanaannya pun dipersiapkan sebelumnya dengan matang. Mulai dari tindakan I siklus I (terdiri dari dua kali pertemuan), serta tindakan II siklus II terdiri dari dua kali pertemuan), dan tindakan
II siklus III terdiri dari dua kali pertemuan). Model Kemmis dan McTarget pada hakikatnya berupa perangkat-perangkat atau untaianuntaian dengan satu perangkat terdiri dari empat komponen, yaitu perencanaan, tindakan, pengamatan, dan refeksi, yang keempatnya merupakan satu siklus.

\section{PEMBAHASAN}

1. Rencana Pelaksanaan Pembelajaran (RPP)

Dalam perencanaan pengajaran dengan menerapkan model pembelajaran Problem Based Learning pada pembelajaran IPS peneliti membuat silabus, membuat rencana pelaksanaan pembelajaran, media berupa gambar visual, lembar observasi implementasi RPP, lembar observasi implementasi KBM, lembar rekapitulasi motivasi siswa, lembar kerja siswa, soal post-tes serta lembar angker siswa.

Penyusunan rencana pelaksanaan pembelajaran (RPP) disesuaikan menurut peratuaran 
menteri pendidikan nasional No.

41 tahun 2007 serta sesuai dengan sintak model Probem Based Learning yaitu meliputi 5 Fase diantaranya : fase 1 mengorganisasikan siswa kepada masalah, fase 2 mengorganisasikan siswa untuk belajra, fase 3 membantu penyelidikan mandiri dan kelompok, fase 4 mengembangkan dan menyajikan, fase 5 menganilisis dan menyajikan. Adapun rincinan komponen RPP adalah sebagai berikut : identitas mata pelajaran, standar kompetensi, kompetensi dasar, indikator pencapaian kompetensi, tujuan pembelajaran, materi ajar, alokasi waktu, langkah-langkah pembelajaran, dan metode pembelajaran.

Rencana

Pembelajaran (RPP) dapat meningkatkan hasil belajar siswa dengan data yang telah dikumpulkan melalui rubik penilain RPP, sedangkan tekhnik pengolaan menggunakan tekhnik analisis seperti pada panduan di BAB III. Hal ini dilakukan untuk mengukur kualitas RPP dengan menerapkan model Problem Based Learning dari setiap komponennya. Hasil analisis data dapat dideskripsikan sebagai berikut :

Pada siklus I mendapatkan persentase sebesar $67,5 \%$ dengan kriteria cukup, pada siklus II mendapatkan persentase 77,5\% dengan kriteria baik dan pada siklus III mendapatkan persentase $90 \%$ dengan kriteria sangat baik. Sehingga penelitian tindakan siklus ini dikatakan berhasil dan tidak perlu diadakan penelitian lagi.

Berdasarkan hasil rencana pelaksanaan pembelajaran (RPP) di atas, peneliti menyimpulkan bahwa penggunaan model pembelajaran Problem Based Learning dapat meningkatkan motivasi dan hasil belajar siswa dalam pembelajaran IPS pada materi peninggaam sejarah kerajaan Buddha di Indonesia. Diharapkan guru dapat mencoba, mengkaji, dan mengimplrmentasikan model pembelajaran tersebut tentang pokok bahasan lainnya pada 
pembelajaran IPS dalam upaya menigkatkan kualitas proses dan hasil belajar mengajar. Maka dengan itu, rencana pelaksanaan pembelajaran (RPP) yang telah dibuat oleh peneliti dinyatakan berhasil.

Sementara pengembangan rencana pelaksanaan pembelajaran (RPP) sesuai dengan fungsi rumusan rencana

pelaksanaan pembelajaran (RPP), menurut Kasful dan Hendra (2011, hlm. 180) sebagai berikut: memperkirakan tindakan yang akan dilakukan guru dalam kegiatan pembelajaran, pedoman guru dalam melaksanakan pembelajaran, dan membantu mempermudah guru dan peserta didik dalam melaksanakan pembelajaran.

\section{Pelaksanaan Pembelajaran}

Pelaksanaa pembelajaran dengan menggunakan model Problem Based Learning adalah model pembelajaran yang berbasis masalah dimana dalam model ini siswa dituntut untuk mencari alternatip jawaban dari permasalahan yang telah diberikan.

Pelaksanaan pembelajarannya meliputi kegiatan pendahuluan, kegiatan inti dan kegiatan akhir yang dikaitkan dengan sintak model Problem Based Learning diantaranya meliputi 5 Fase fase 1 mengorganisasikan siswa kepada masalah, fase 2 mengorganisasikan siswa untuk belajra, fase 3 membantu penyelidikan mandiri dan kelompok, fase 4 mengembangkan dan menyajikan, fase 5 menganilisis dan menyajikan.

Berdasarkan hasil penelitian tindakan kelas (PTK) dengan menggunakan model Problem Based Learning , guru merefleksi perencanaan, proses dan hasil siswa dalam pelaksanaan pembelajaran. Hasil analisis data dapat dideskripsikan sebagai berikut : Penilaian pelaksanaan pembelajaran pada siklus I peneliti mendapatkan persentase 62,9 dengan kategori cukup, pada siklus II peneliti mendapatkan persenatse $\quad 77,5 \%$ dengan kategori baik dan pada siklus III peneliti mendapatkan persentase 
$90 \%$ dengan katogeri sangat baik. Sehingga hal ini dapat dikatakan berhasil pada siklus III dan tidak perlu diadakan penelitian lagi.

Berdasarkan hasil penelitian pelaksanaan pembelajaran di atas dapat disimpulkan bahwa penggunaan model Problem Based Learning dapat meningkatkan motivasi daa hasil belajar siswa dalam pembelajaran IPS materi peninggalan sejarah kerajaan Buddha di Indoensia. Diharapkan guru dapat mencoba, mengkaji dan mengimplementasikan model pembelajaran tersebut pada pokok bahasan lainnya dalam pebelajaran IPS untuk meningkatkan kualitas proses dan hasil belajar IPS.

\section{Motivasi Belajar Siswa}

Berdasarkan hasil penelitian tindakan kelas (PTK) dengan menggunakan model Probem Based Leraning dapat meningkatkan motivasi belajar siswa, bisa dikatakan berhasil karena melihat dari kelebihan model Problem Based Learning . Adapun kelebihan model Problem
Based Learning antara lain: siswa akan terbiasa menghadapi masalah dan tertantang untuk menyelesaikan masalah tidak hanya terkait dengan pembelajaran di kelas tetapi juga menghadapi masalah yang ada dalam kehidupan sehari-hari, memupuk solidaritas sosial dengan terbiasa berdiskusi dengan temanteman, makin mengakrabkan guru dengan siswa, dan membiasakan siswa melakukan eksperimen.

Melihat dari kelebihan model Problem Based Learning yang dipaparkan di atas menjadikan siswa lebih aktif dan antusias dalam mengikuti proses pembelajaran,sehingga dengan pemebelajaran aktif akan menggugah motivasi dalam mengikuti jalannya pembelajaran. Hal ini dapat dibuktikan bahwa adanya peningkatan motivasi siswa dalam pembelajaran IPS dengan menggunkan model Problem Based Leraning setiap siklusnya. Hasil analisis data dapat dideskripsikan sebagai berikut : pada siklus I peneliti memperoleh persentase dengan nilai rata-rata 
65\%, pada siklus II peneliti memperoleh persentase dengan nilai rata-rata $75,7 \%$ dan pada siklus III peneliti memperoleh persentase dengan nilai rata-rata 88\%. Maka dapat disimpulkan bahwa dengan menggunakan model pembelajaran Problem Based Leraning dapat menigkatkan motivasi belajar siswa dalam pembelajaran IPS pada materi peninggalan sejarah kerajaan Budha di Indonesia.

Dari penjelasan di atas dapat disimpulkan bahwa motivasi siswa yang diperoleh pada sikus I, II dan III dengan menggunkan mode Problem Based Leraning dapat meningkatkan motivasi siswa dalam pembelajaran IPS materi peninggalan sejarah kerajaan Budha di Indonesia.

\section{Hasil Belajar Siswa}

Hasil belajar siswa merupakan hasil akhir dari proses pembelajaran. Berdasarkan hasil penelitian tindakan kelas (PTK) dengan menggunakan model Probem Based Leraning dapat meningkatkan hasil belajar siswa, bisa dikatakan berhasil karena melihat dari kelebihan model Problem Based Learning . Adapun kelebihan model Problem Based Learning antara lain: siswa akan terbiasa menghadapi masalah dan tertantang untuk menyelesaikan masalah tidak hanya terkait dengan pembelajaran di kelas tetapi juga menghadapi masalah yang ada dalam kehidupan seharihari, memupuk solidaritas sosial dengan terbiasa berdiskusi dengan teman-teman, makin mengakrabkan guru dengan siswa, dan membiasakan siswa melakukan eksperimen.

Dalam penelitian ini untuk hasil belajar siswa berupa Post-tes adapun hasil akhirnya adalah sebagai berikut : siklus । persentase nilai post-tes yang diperoleh adalah 13 atau 59\%, dari jumlah siswa 22 orang. Pada sikus II siswa yang memenuhi KKM adalah 16 atau 73\%, dari jumlah 22 orang dan pada siklus III siswa yang memenuhi KKM adalah 20 atau 90\%, dari jumlah 22 orang.

Dari penjelasan di atas dapat disimpulkan bahwa hasil belajar 
siswa yang diperoleh pada sikus I, II dan III dengan menggunkan mode Problem Based Leraning dapat meningkatkan hasil belajar siswa dalam pembelajaran IPS materi peninggalan sejarah kerajaan Budha di Indonesia.

\section{E. KESIMPULAN}

Rencana

perencanaan pembelajaran (RPP) yang telah dibuat sesuai dengan Permendiknas No. 41 tahun 2007 tentang standar proses dan komponen rencana pelaksanaan pembelajaran yang meliputi identitas terdiri dari nama sekolah, dan alokasi waktu, indikator, tujuan pembelajaran, materi pembelajaran, metode pembelajaran, kegiatan pembelajaran terdri dari kegiatan awal, inti dan kegiatan akhir, sumber belajar, dan penilaian. Secara umum rencana pelaksanaan pembelajaran (RPP) yang peneliti buat telah terlaksana dengan baik. Hal tersebut ditandai dengan adanya penilaian lembar observasi ketercapain pelaksanaan pembelajaran (RPP) yang diberikan observer mengaami peningkatan yang signifikan pada setiap siklusnya. Rencana pelaksanaan pembelajaran pada siklus I peneliti mendapatkan persentase $67,5 \%$ kategori cukup, siklus II peneliti mendapatkan persentase $77,5 \%$ kategori baik, dan pada siklus III peneliti mendapatkan persentase $90 \%$ kategori sangat baik. Dengan kata lain maka dapat disimpilkan bahwa dengan menerapkan model Problem Based Learning dapat meningkatkan motivais dan hasi belajar siswa kelas V SD Negeri Cikaret Kabupaten Cianjur dalam pembelajaran IPS pada materi peninggalan sejarah kerajaan Buddha di Indonesia.

Pelaksanaan pembelajaran yang dilakukan sesuai dengan sintak model Problem Based Learning yang terdiri dari lima fase yaitu, fase 1 mengorganisasikan siswa pada masalah, fase 2 mengorganisasikan siswa untuk belajar, fase 3 membantu penyelidikan mandiri dan kelompok, fase 4 mengembangkan dan menyajikan, fase 5 
menganalisis dan mengevaluasi.

Secara umum pelaksanaan pembelajaran yang peneliti buat telah terlaksana dengan baik. Hal tersebut ditandai dengan adanya penilaian lembar observasi pelaksanaan pembelajaran yang diberikan observer mengalami peningkatan yang signifikan pada setiap siklusnya. Pelaksanaan pembelajaran pada siklus I peneliti mendapatkan persentase 62,9\% kategori cukup, siklus II peneliti mendapatkan persentase 77,5\% kategori baik, dan pada siklus III peneliti mendapatkan persentase 90\% kategori sangat baik. Maka dapat disimpilkan bahwa dengan menerapkan model Problem Based Learning dapat meningkatkan motivasl dan hasi belajar siswa kelas V SD Negeri Cikaret Kabupaten Cianjur dalam pembelajaran IPS pada materi peninggalan sejarah kerajaan Buddha di Indonesia.

Melalui mode Problem Based Learning dapat meningkatkan motivasi siswa. Hal tresebut dilihat dari peningkatan hasil indikator motivasi belajar siswa yaitu (a).adanya hasrat dan keinginan berhasil, (b). adanya dorongan dan kebutuhan dalam belajar (c). adanya harapan dan cita-cita masa depan, (d). adanya kemauan untuk belajar (e). membentuk keterampilan siswa pada setiap sikulusnya. Pelaksanaan pembelajaran pada siklus I hasil motivasi siswa mencapai persentase 65\% kategori cukup, siklus II peneliti mendapatkan persentase $77,5 \%$ kategori baik, dan pada siklus III peneliti mendapatkan persentase $88 \%$ kategori baik. Maka dapat disimpilkan bahwa dengan menerapkan model Problem Based Learning dapat meningkatkan motivas dan hasil belajar siswa kelas V SD Negeri Cikaret Kabupaten Cianjur dalam pembelajaran IPS pada materi peninggalan sejarah kerajaan Buddha di Indonesia.

Melalui penerapan model Problem Based Learning dapat meningkatkan haisl beajar siswa . hal tersebut ditandai dengan adanya peningkatan yang signifikan pada setiap siklusnya. 
Hasil belajar siswa pada siklus I siswa yang mencapai KKM sebesar 59\% kategori cukup, siklus II siswa yang mencapai KKM mendapatkan persentase $73 \%$ kategori baik, dan pada siklus III siswa yang menacapai KKM sebesar $90 \%$ kategori sangat baik. Maka dapat disimpulkan bahwa dengan menerapkan model Problem Based Learning dapat meningkatkan motivas dan hasil belajar siswa kelas V SD Negeri Cikaret Kabupaten Cianjur dalam pembelajaran IPS pada materi peninggalan sejarah kerajaan Buddha di Indonesia.

$$
\text { Berdasarkan }
$$

hasil

pembahasan pada penelitian ini dapat disimpulkan bahwa rencana pelaksanaan pembelajaran (RPP) dan pelaksanaan pembelajaran dengan menerapkan model Problem Based Leraning dapa meningkatkan motivas dan hasil belajar siswa kelas V SD Negeri Cikaret Kabupaten Cianjur dalam pembelajaran IPS pada materi peninggalan sejarah kerajaan Buddha di Indonesia.

\section{DAFTAR PUSTAKA}

Hamzah . B. Uno. (2014). Teori

Motivasi \& Pengukurannya.

Gorontalo. Bumi Askara

Karwati Euis \& Donni. (2014).

Manajemen Kelas. Bandung :

Alfabeta

Kurniasih. (2010). Landasan

Pendidikan Sekolah Dasar.

Bandung : Percikan IImu

Nanang Hanafiah \& Cucu

Suhana.(2012). Konsep

Strategi Pembelajaran.

Bandung : PT Refika

Aditama.

Nurmansah, Irman .(2008).

Penggunaan Metode Role Playing untuk Meningkatkan Hasil Belajar Siswa pada materi Perjuangan Para Tokoh masa Penjajahan. Skripsi UPI. Tidak Diterbitkan. Trisa. Yuniarti. (2009).

Meningkatkan Aktivitas dan Hasil Belajar Siswa Pada Pembelajaran IPS Tentang Peninggalan Sejarah Kerajaan Budha Di Indonesia Melalui Model Make A di Kelas $V$. Skripsi UNPAS :

Tidak Diterbitkan. 
Fera, Indriyani. (2009).

Penggunaan

Model

Pembelajaran

Numbered

Head Together Untuk

Meningkatkan Pemahaman

Konsep Siswa Pada

Pembelajaran Ips Tentang

Keragaman Suku Bangsa Di

Indonesia. Skripsi UNPAS :

Tidak Diterbitkan.

Sudaryono. (2012). Dasar-dasar evaluasi

pembelajaran.

Tangerang: Graha IImu

Barrows \& R.M Tamblyn. (1980).

Probem Based Learning : An Approach

To Medical Education. New

Yoark: Springger Publishing.

Oemar, Hamalik. (2011). Proses

Belajar Mengajar. Bandung :

PT Bumi Askara.

Rusmono. (2014). Strategi

Pembelajaran dengan

Problem Based Learning itu perlu. Jakarta : Ghalia Indonesia.

Ridwan, Abdul Sani. (2014).

Pembelajaran Saintifik untuk Implementasi Kurikulum 2013. Jakarta : PT Bumi Askara
Rusman.(2012). Belajar dan Pembelajaran Berbasis Komputer Mengembangkan Profesionalisme Guru Abad 21. Bandung: ALFABETA.

Trianto.

(2011).

Model

Pembelajaran

Terpadu

Konsep, strategi, Dan Implementasinya dalam Kurikulum Tingkat Satuan Pendidikan. Jakarta : Bumi Aksara.

Rusman. (2010). Model-model pembelajaran

mengembangkan

profesionalisme guru.

Bandung: Raja Grapindo Persada.

Taniredja, Tukiran, dkk. (2011). Penelitian Tindakan Kelas Untuk Mengembangkan Profesi Guru Praktik, Praktis, dan Mudah. Bandung: Alfabeta.

Uno, dkk. (2011). Menjadi peneliti PTK yang profesional. Jakarta: Bumi Aksara

Kunandar. (2008). Langkah Mudah Penelitian Tindakan Kelas Sebagai Pengembangan Profesi 
Guru. Jakarta: PT

Rajagrafindo Persada.

Mulyasa. (2009). Praktik

penelitian tindakan kelas.

Bandung: PT Remaja

Rosdakarya.

Muslich, Mansur. (2009).

Melaksanakan PTK Itu

Mudah. Jakarta: Bumi

Aksara

Majid, Abdul. (2007). Perencanaan

Pembelajaran. Bandung: PT

Remaja Rosdakarya

Slameto.(2003). Belajar dan factor-

faktor yang mempengaruhinya.

Jakarta: PT. Rineka cipta.

Trianto.(2011). Panduan Lengakap

Penelitian Tindakan Kelas.

Surabaya:Prestasi

Pustakarya

Sugiyono. (2012). Metode

Penelitian Kuantitatif

Kualitatif dan R\&D. Bandung :

Alfabeta.

Tim Bina IPS. (2010).IImu

Pengetahuan Sosial. Jakarta :

Yudhistira. 